\title{
Oral hygiene level of children with cerebral palsy
}

\author{
Debrina Mayasari Soekamto*, Iwan Ahmad Musnamirwan*, Inne Suherna Sasmita* \\ *Department of Pedodontics Faculty of Dentistry Universitas Padjadjaran
}

\begin{abstract}
Introduction: Dental and oral hygiene is important in supporting oral health in particular and general body health. Dental and oral hygiene can be maintained by controlling plaque. The aim of the study was to obtain data on the level of dental and oral hygiene in cerebral palsy children in the Sekolah Luar Biasa Bagian D Yayasan Pembinaan Anak Cacat, Sukajadi, Bandung. Methods: The research method is descriptive. Samples were obtained by total sampling technique which has criteria for children under 18 years old. A total of 43 children were obtained from all cerebral palsy children. Data were obtained by clinical examination, to calculate the level of dental and oral hygiene, OHI-S from Green and Vermillion was used by applying disclosing solution on the tooth surface, with criteria: good if the $\mathrm{OHI}$ value $=0.1-1.2$; mean if the value of $\mathrm{OHI}=1.3-3.0$; bad if the value of $\mathrm{OHI}=3.1-6.0$. Result: The results showed that the average dental and oral hygiene of cerebral palsy children in the Sekolah Luar Biasa Bagian D Yayasan Pembinaan Anak Cacat, Sukajadi, Bandung was 3.27. Conclusion: Dental and oral hygiene in cerebral palsy children in Sekolah Luar Biasa Bagian D Yayasan Pembinaan Anak Cacat, Sukajadi, Bandung is included in the bad criteria.
\end{abstract}

Keywords: Dental and oral hygiene, plaque index, calculus index, cerebral palsy.

\section{INTRODUCTION}

The policy of equal distribution of education for all children of the nation is a realization of the mandate of UUD 1945 (amendemen) pasal 31 ayat 2 which states that every citizen is obliged to attend basic education, and the government is obliged to finance it; and UU Nomor 20 tahun 2003 tentang Sisdiknas pasal 7 ayat 2 that parents of children of compulsory age of study are obliged to provide basic education to their children. ${ }^{1}$ Children of compulsory education do not all have normal physical, emotional, and social, among them there are those who have disabilities (with special needs). According to the Sensus Nasional Biro Pusat Statistik in year 2003, the number of children with special needs for school-age (5-18 years) in Indonesia is $21.42 \%$ or 317,016 children from the number of persons with special needs in Indonesia which amount to $0.7 \%$ or $1,480,000$ people out of a total population of $211,428,572$ people. $^{2}$

The number of children with special needs increases each year, so statistics are obtained, the number of children with special needs of schoolage increased to 321,000 children in $2007 .{ }^{3}$ Children with special needs are entitled to the widest 
educational opportunity in accordance with their respective conditions and abilities. ${ }^{4}$ The basis for obtaining education for those with special needs, is legally stated in UU Nomor 20 tahun 2003 tentang Sisdiknas pasal 5 ayat 2 that citizens with physical, emotional, mental, intellectual and / or social disabilities are entitled to special education. ${ }^{5}$ According to the Direktorat Pendidikan Luar Biasa (2006), special education in the form of Special Schools (Sekolah Luar Biasa) consists of four types, namely SLB part A for the visually impaired, SLB part $B$ for the hearing impaired, SLB part $C$ for the mentally disabled, SLB part $D$ for physical impaired. ${ }^{6}$

The only Special School part D in West Java Province is the Yayasan Pembinaan Anak Cacat (SLB-D YPAC) Bandung. Physical impaired is another term for bodily disability; that is, various bodily deformities that result in abnormal functioning of the body to perform the movements needed. ${ }^{7}$

Physical impaired classification in terms of abnormalities are grouped into two major parts, namely abnormalities in the cerebral system (cerebral system) and muscle and skeletal (musculo skeletal system), including cerebral system abnormalities are cerebral palsy The number of children and adults affected by cerebral palsy still seems to be unchanged or perhaps increased slightly over the past 30 years. The incidence of cerebral palsy ranges from 1.2 - 2.5 children per 1000 children of early school age. ${ }^{6}$

According to a study estimated that 200,000 children in the United States suffer from cerebral palsy. Increased obstretic and perinatalogy services and low birth rates in developed countries such as Europe and the United States have caused the incidence of cerebral palsy to decrease. The incidence of cerebral palsy in developing countries is higher at $2-2.5$ per live birth. The higher incidence is due to developing countries having limited advances in medical technology that can increase mortality rates for high-risk babies and the number of children with developmental disorders. ${ }^{7,8}$

Cerebral palsy is a term that includes non-progressive motor disorders that are seen during the initial phase of development due to lesions or anomalies in the brain. In the form of motor impairment in cerebal palsy children is spastic (stiff), diskinetic (movement disorder), including in that group is dystonia (loss of tension), or rigidity ( tightening muscles). Other manifestations are ataxia (loss of control of muscle movements), or mixed disorders occur, such as stiffness and loss of motion control. Fifty percent of children with cerebral palsy have mild motor damage, $25 \%$ have moderate motor damage, and the remaining $25 \%$ have severe motor damage that requires total help from others in their motor activities. ${ }^{9}$

Motoric damage in children with cerebral palsy in the form of reduced muscle coordination and imperfect motoric function causes minimal masticatory muscle function and difficulty maintaining oral hygiene. ${ }^{10}$ Difficulties in maintaining oral hygiene result in poor oral hygiene conditions occurring, even with gingivitis and plaque accumulation. Oral hygiene that is left without treatment can undermine general health status. Dentists play an important role in a multidisciplinary approach in the health care of cerebral palsy patients accompanied by neuromuscular abnormalities. ${ }^{11}$

According to the National Institute of Neurological Disorders and Stroke (2006), early and routine dental examinations and treatments can improve the oral health of children with cerebral palsy. The results of Irmaleny's research (1989) in the Sekolah Luar Biasa Bagian D Yayasan Pembinaan Anak Cacat, Sukajadi, Bandung, showed that the level of oral and dental hygiene of cerebal palsy children based on plaque and calculus indexes according to Green and Vermillion was 3.56.

The results of the study showed that the average oral hygiene index of cerebral palsy children in the Sekolah Luar Biasa Bagian D Yayasan Pembinaan Anak Cacat, Sukajadi, Bandung was in condition of poor. Organizational data from Sekolah Luar Biasa Bagian D Yayasan Pembinaan Anak Cacat in 2009 showed the number of cerebral palsy sufferers was $88.68 \%$ of the total students, while the rest were autistic.

From the background above, the author is interested in reexamining the level of oral and dental hygiene in cerebral palsy children in Sekolah Luar Biasa Bagian D Yayasan Pembinaan Anak Cacat, Sukajadi, Bandung.The purpose of this study was to obtain data on the level of oral and dental hygiene in cerebral palsy children, as well as evaluation materials for medical staff and teaching staff in Part Special School Foundation 
Child Disability Development, Sukajadi, Bandung.

\section{METHODS}

The type of research used is descriptive survey technique. The study population was children with cerebral palsy at the Sekolah Luar Biasa Bagian D Yayasan Pembinaan Anak Cacat, Sukajadi, Bandung. The research sample was taken by total sampling technique with the criteria of children under 18 years old. Plaque is a soft deposit on the tooth surface that does not come off after rinsing, but can be removed mechanically by using a dental explorer. Plaque will give a red picture if the disclosing solution is applied. Calculus is a hard deposit that cannot be removed mechanically using a dental explorer and its presence can be marked by the roughness of the surface being traced. Calculus can be yellow to black. Students who are able to study at Sekolah Luar Biasa Bagian D and are declared to have cerebral palsy abnormalities by a doctor on duty at the school.

The study was conducted on all types of cerebral palsy. Tools used in the research are status sheet, mouth mirror, dental explorer, dental tweezer, cup, cotton, stationary, mask, glove, headlamp, alcohol $70 \%$, cotton pellet, disclosing solution. Clinical examination is done by measuring the plaque index and calculus using the Oral Hygiene Index $(\mathrm{OHI})$ of Green and Vermillion in 1960. The examination is carried out on certain tooth surfaces based on the extension towards the crown and not its thickness.

The examination is carried out systematically on the surface of the teeth, which is assessment for the maxilla and assessment for the mandible. The assessment for the maxilla was carried out as follows: 1 ) Upper right I1 tooth (1.1) on the labial surface; 2) Upper right M1 tooth (1.6) on the buccal surface; 3) Upper left M1 tooth (2.6) on the buccal surface. The assessment for the lower jaw was carried out as follows: 1) Lower left tooth I1 (3.1) on the labial surface ; 2 ) Lower left M1 tooth (3.6) on the lingual surface ; 3 ) Lower right $M 1$ tooth (4.6) on the lingual surface. If there is a case of one of the tooth missing (extracted/retained root), the assessment is made on the replacement teeth that have been assigned to represent it, as follows : 1) If tooth 1.1 is absent, assessment is made on tooth $2.1 ; 2$ ) If there are no teeth 1.1 and 2.1, no assessment can be made; 3 ) If tooth 3.1 is absent, assessment is made on tooth $4.1 ; 4)$ If there are no teeth 3.1 and 4.1 , no assessment can be made; 5 ) If upper or lower maxillary M1 teeth are absent, an assessment can be made on $M 2$ teeth If there are cases of several teeth among the six teeth that should be examined are absent, the plaque index can still be calculated if there are at least 2 teeth that can be assessed.

The criteria for evaluating plaque index according to Green and Vermillion are as follows: $0=$ no plaque or stain was seen; 1 = visible soft plaque covering $1 / 3$ or less than $1 / 3$ surface gum; $2=$ on the surface of the teeth visible soft plaque that covers more than $1 / 3$ of the gum and less than $2 / 3$ the middle of the tooth surface; $3=$ on the surface of the teeth visible soft plaque that covers $2 / 3$ of the tooth surface.

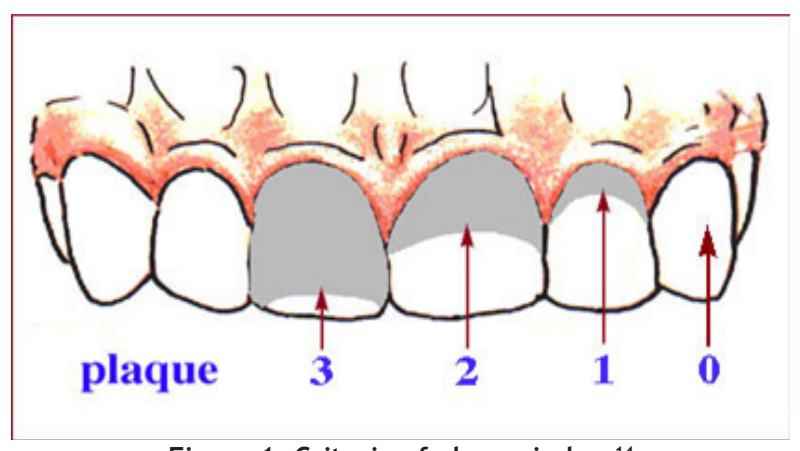

Figure 1. Criteria of plaque index. ${ }^{14}$

To determine the individual plaque index, the formula for the total number of plaque values per tooth divided by the total number of teeth surfaces examined. Criteria for the status of plaque index according to Green and Vermillion are as follows: 1) Good if the value of the plaque index $=0.0-0.6 ; 2$ ) Medium if the value of the plaque index $=0.7-1.8 ; 3$ ) Poor if the value of the plaque index $=1.9-3.0$.

The criteria for calculating according to Green and Vermillion are: $0=$ no calculus is seen; $1=$ on the surface of the teeth there is a supragingival calculus covering $1 / 3$ or less than $1 / 3$ of the tooth surface gingiva; 2 = on the surface of the teeth seen supragingival calculus that covers more than $1 / 3$ or less than $1 / 3$ of the tooth surface gingiva; $3=$ on the surface of the teeth there is supragingival calculus that covers more than $2 / 3$ of the tooth surface or if there are subgingival calculi that cover and encircle the entire surface 
of the tooth. To determine the individual calculus index, the formula for the total number of calculus values per tooth is divided by the total number of surfaces of teeth examined. Criteria for calculus index status according to Green and Vermillion are as follows: 1) Good if the value of calculus index $=0.0-0.6 ; 2$ ) Medium if the calculus index value $=0.7-1.8 ; 3$ ) Poor if the calculus index value $=1.9-3.0$. To determine the oral hygiene index, the plaque index formula is used to add the calculus index.

Criteria for oral hygiene status according to Green and Vermillion are: 1) Good if the value of $\mathrm{OHI}=0.1-1.2 ; 2$ ) Medium if the value of $\mathrm{OHI}$ $=1.3-3.0 ; 3)$ Poor if the value of $\mathrm{OHI}=3.1-6.0$ .Data obtained from the results of the study were collected, recorded, evaluated and then arranged in a tabular form to find out the picture of the level of dental and oral hygiene in cerebral palsy children in Sekolah Luar Biasa Bagian D Yayasan Pembinaan Anak Cacat, Sukajadi, Bandung.

\section{RESULTS}

Research has been carried out on all cerebral palsy children in Sekolah Luar Biasa Bagian D Yayasan Pembinaan Anak Cacat, Sukajadi, Bandung. The overall number of respondents showed more men (55.81\%) compared to women (44.19\%). The age of respondents ranged from 7-17 years, and most were respondents aged 10-17 years. The oral hygiene index of respondents was obtained using the Oral Hygiene Index-Symplified method from Green and Vermillion. A description of $\mathrm{OHI}-\mathrm{S}$ respondents can be seen in Table 1.

Table 1. Frequency distribution of plaque index

\begin{tabular}{cccc}
\hline Plaque index & Criteria & Frequency & $\%$ \\
\hline $0.0-0.6$ & Good & 0 & 0 \\
$0.7-1.8$ & Fair & 2 & 4.65 \\
$1.9-3.0$ & Bad & 41 & 95.35 \\
\hline Total & & 43 & 100 \\
\hline
\end{tabular}

Table 2. Frequency distribution of calculus index

\begin{tabular}{cccc}
\hline Plaque index & Criteria & Frequency & $\%$ \\
\hline $0.0-0.6$ & Good & 14 & 32.56 \\
$0.7-1.8$ & Fair & 29 & 67.44 \\
$1.9-3.0$ & Bad & 0 & 0 \\
\hline Total & & 43 & 100 \\
\hline
\end{tabular}

Oral hygiene index is a number that shows the level of oral and dental hygiene obtained by adding up the average plaque index and the average calculus index. The average frequency distribution of plaque index, calculus and oral and dental hygiene are shown in Table 3.

Table 3. The average frequency distribution of plaque index, calculus and oral hygiene

\begin{tabular}{ccc}
\hline Plaque index & Criteria & Frequency \\
\hline Plaque & 2.57 & Good \\
Calculus & 0.70 & Fair \\
Oral hygiene & 3.27 & Bad \\
\hline
\end{tabular}

Table 4. Frequency distributions Average - Average index of plaque, calculus, and oral hygiene by gender

\begin{tabular}{cccc}
\hline Gender & Criteria & Frequency & $\%$ \\
\hline Female & 2.55 & 0.74 & 3.29 \\
Male & 2.58 & 0.66 & 3.25
\end{tabular}

Table 5. Distribution of respondents' OHI-S frequencies

\begin{tabular}{ccc}
\hline OHI - S & Criteria & Frequency \\
\hline Good & 0 & 0 \\
Fair & 12 & 27.91 \\
Bad & 31 & 72.09 \\
\hline Total & 43 & 100 \\
\hline
\end{tabular}

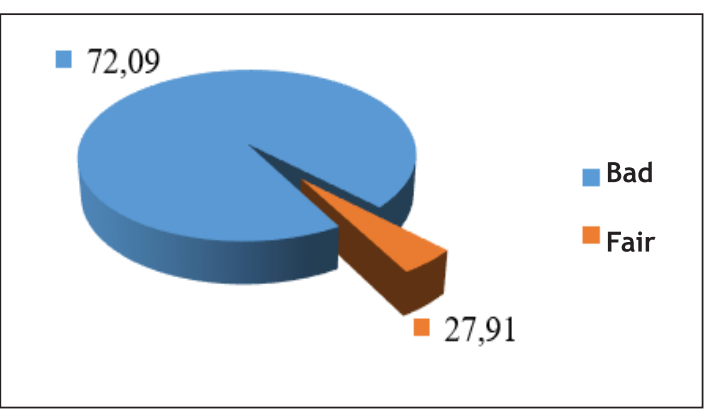

Figure 2. Percentage assessment of oral and dental hygiene index

This research of threshold differences of taste tasting before and after using a mouthwash containing zinc sulfate was performed on 30 sample. The study used a solution of sucrose with a concentration of $0.0006 \mathrm{M}$ to $0.06 \mathrm{M}$ as a solution to test the sweet taste tasting threshold value.

Based on the results of the research, the values of the tasting threshold consisted of the value of the perception threshold and the threshold value of identification each measured before and after using a mouthwash containing zinc sulfate. The perceptual threshold is obtained when 
the sample can distinguish the test solution from water but has not been able to confirm the taste type.

The threshold of identification is obtained when the sample can recognize and specify the type of taste of the test solution with specific and precise. The data were analyzed by paired student $t$ test statistic method to find out whether there was a difference of sweet taste threshold value before and after using mouthwash containing zinc sulfate.

The statistical calculation yields data in the mean, mode, median, standard deviation and $\mathrm{t}$ arithmetic from the perception threshold and the sweet taste identification threshold before and after using a mouthwash containing zinc sulfate shown in Table 1 and Table 2. Table 1 shows the maximum and minimum tasting taste perception threshold values before using a mouthwash containing zinc sulfate is 0.0200 and 0.0006 with mean and standard deviation values of 0.0046 and 0.0047 .

After using a mouthwash containing zinc sulfate obtained a maximum value of 0.0360 and the minimum value to 0.0010 with an average of 0.0128 and standard deviation of 0.0084 . The result of statistical test with the criterion of starting test $\mathrm{wH} 0$ if tcount $\geq \mathrm{t}$ table or $\mathrm{t}$ count $\leq$ - ttable indicates that $\mathrm{HO}$ rejected, then it is concluded that there is a significant difference between sweet taste perception threshold before and after using mouthwash containing zinc sulfate.

Table 2 shows the maximum and minimum taste taste sweetening taste verification threshold values before using a mouthwash containing zinc sulfate is 0.0360 and 0.0010 with mean and standard deviation values of 0.0164 and 0.0089 . After using a mouthwash containing zinc sulfate obtained a maximum value of 0.0440 and the minimum value to 0.0120 with an average of 0.0248 and standard deviation of 0.0082 .

The result of statistical test with the criterion of starting test $\mathrm{HO}$ if tcount $\geq$ ttable or tcount $\leq$ - ttable indicates that $\mathrm{HO}$ is rejected, it is concluded that there is a significant difference between the threshold of sweet taste identification before and after using mouthwash containing zinc sulfate.

\section{DISCUSSION}

Table 1 shows that the plaque index on the most respondents is with bad criteria of 41 children (95.35\%). Plaque will easily form if oral and dental hygiene is ignored. According to the National Institute of Neurogical Disorders and Stroke (2006), children with cerebral palsy experience mental retardation which results in them not having the understanding and ability to clean teeth and mouth. Impaired vision also occurs in children with cerebral palsy so that they cannot determine whether their teeth are clean or still dirty.

Difficulty in brushing teeth causes the process of cleaning teeth and mouth is less than perfect so that the tooth surface that has been brushed still holds plaque. Plaque control has an important role in maintaining oral hygiene and can be done in two ways, namely mechanically and chemically. Mechanical methods are easier to do such as brushing teeth, dental floss, and gargling.

According to the National Institute of Neurogical Disorders and Stroke (2006), brushing teeth for normal children is normal and simple and can be implemented well, but for children with cerebral palsy brushing can be very difficult. Difficulty in brushing teeth can be caused by cerebral palsy children by having uncontrolled limb movements. The limbs of a child with cerebral palsy more often move uncontrollably differently from a normal child. When cerebral palsy children try to move normally, their muscles often tense and cause uncontrolled motion or also called primitive reflexes.

Primitive reflexes that are common in children with cerebral palsy are factors that can also complicate the maintenance of oral and dental hygiene. Primitive reflexes that occur when the head moves or the child is shocked and tries to control himself can lead to movements that are more out of control.

Some types of primitive reflexes that are often found during dental and oral hygiene treatments are neck tonic asymmetry reflexes, tonic labyrinth reflexes, and startle reflexes. Neck tonic asymmetry reflex is a reflex that occurs when the child's head changes position, arms and legs on the opposite side stick out stiffly. Tonic labyrinth 
reflexes are reflexes that occur when the neck is pulled when a child is leaning on his back, his arms and legs can also be attracted, and his back and neck are curved. Reflex startle is all that surprising stimuli, such as a surprising scene or movement of interlocutor can trigger uncontrolled movements and powerful, including the entire body. Table 2 shows that the majority of respondents had a moderate calculus index of 29 children (67.44\%) which showed that cerebral palsy children were less able to clean their mouths.

Between plaque and calculus have a close relationship; mass of plaque that is not cleaned will experience mineralization to form calculus. Plaque will undergo calcification which results in binding of calcium phosphate salt crystal deposits.

The calcification process takes place continuously so that the plaque mass increases and unites to form a solid calculus mass. Bacteria play an important role in the process of precipitation of calcium salts in calcification. As time passes, plaque will turn into calculus. Lack of dental hygiene at a young age will cause a large deposition of calculus in adolescence and adulthood, if they continue to neglect oral and dental hygiene.

Prevention of calculus formation can be done by preventing and controlling plaque formation, and as soon as possible cleaning plaque that is formed, as mentioned earlier that brushing teeth is the most effective way to prevent plaque formation, calculus formation can also be prevented in the same way. According to the $\mathrm{Na}$ tional Institute of Neurogical Disorders and Stroke (2006), electrical toothbrushes can help children with cerebral palsy in overcoming the difficulties of brushing their teeth.

Electrical toothbrushes are specially designed to make it easier for cerebral palsy children to hold the toothbrush. Electrical toothbrushes help children not to exert too much energy to clean their teeth and mouth. The use of an electrical toothbrush should be recommended to children with cerebral palsy. Talking about the effectiveness of electrical and manual toothbrushes, research shows a real advantage in electrical toothbrushes compared to manuals.

Electrical toothbrushes are proven to be significantly better than manual toothbrushes in reducing plaque and gingivitis. Table 3 shows that the average oral hygiene index of respondents that has bad criteria (3.27), the average plaque index shows bad criteria (2.57), and the average calculus index indicates moderate criteria $(0.70)$ . High plaque and calculus index values indicate poor oral hygiene index values. Factors that result in poor oral hygiene of cerebral palsy children is their inability to control their motor movements in cleaning their teeth and mouth.

Other factors that influence poor dental and oral hygiene of cerebral palsy children can be the tendency of parents to pamper their children suffering from cerebral palsy with soft and cariogenic food, and the increasing prevalence of dental enamel hypoplasia. The presence of motoric facial muscle disorders, mastication and ingestion will cause cerebral palsy children to only be able to eat only soft foods while soft foods do not have the effect of self-cleansing.

Table 4 shows that the gender that showed a comparison of oral hygiene index values between women and men were almost the same, namely women with bad criteria (3.29), and men with bad criteria (3.25). The difference in gender of children with cerebral palsy does not affect the oral hygiene index, but the physical condition of children with cerebral palsy does not allow them to brush their teeth. According to Irmaleny's 1989 study, the oral hygiene index of cerebral palsy children is different from the condition in normal children. Index of oral hygiene in normal girls is better than boys, this is because girls are more concerned with appearance with a mouth that looks clean than boys.

Table 5 and diagram 4.1 show that the majority of respondents have $\mathrm{OHI}-\mathrm{S}$ with bad criteria, namely 31 children $(72.09 \%)$ and moderate criteria for 12 children (27.91\%). Results of research which are dominated by bad criteria are not different from Irmaleny research results in 1989, this is caused by various factors.

The main influencing factor is the condition of motoric movement of cerebral palsy children which is limited in maintaining oral and dental hygiene, besides the lack of attention of institutions and health workers in Bandung towards the prevention and maintenance of oral and dental hygiene of cerebral palsy children especially in Sekolah Luar Biasa Bagian D Yayasan Pembinaan Anak Cacat, Sukajadi, Bandung.

The absence of Usaha Kesehatan Gigi Seko- 
lah (UKGS) reflects the lack of concern for schools and teaching staff on the oral and dental health of their students. Another thing that also affects the poor oral hygiene of cerebral palsy children attending the Sekolah Luar Biasa Bagian D Yayasan Pembinaan Anak Cacat in Bandung is the parents' trust in caregivers who have less knowledge and concern for the maintenance of oral and dental hygiene of cerebral palsy children, whereas according to Notoatmodjo (2003), parents and especially mothers are the main target of health education, because parents are the foundation of their children's health behavior.

The high cost of electric toothbrushes does not support parents of cerebral palsy children to maintain the cleanliness of their children's teeth and mouth, so the toothbrush that is often used is a manual toothbrush that is less effective in cleaning the teeth and mouth of a cerebral palsy child.

The role of parents who are completely limited (both from action and knowledge) worsens the already poor condition, thus further worsening the problem of oral hygiene. Therefore it is very important for the role of the dentist to help guide and maintain the oral hygiene of children with cerebral palsy.

The lack of knowledge of dentists in dealing with the care of cerebral palsy children is also a factor that supports the prevention and maintenance of oral hygiene of cerebral palsy children, this was obtained by the authors from the results of observations and discussions on oral and dental counseling with parents and caregivers of cerebral palsy children in the Sekolah Luar Biasa Bagian D Yayasan Pembinaan Anak Cacat.

Parents and caregivers complained about some of the attitudes of dentists who shift their duties to other dentists in their children's oral and dental care, due to the lack of dentist competence in dealing with cerebral palsy during oral and dental care. The success of dental care in children with cerebral palsy requires a close collaboration with the parent and the operator.

The condition of cerebral palsy children who cannot be collaborated with during dental treatment by a dentist can be physically controlled. Physical control can be carried out using wheel chair headrest, restraints, and body support devices; if physical restraint is considered less successful, could be given premedication clordiazep- oxide hydrochloride (Librium), a drug which often used to reduce anxiety and spasm of the muscles. ${ }^{6}$

\section{CONCLUSION}

Oral and dental hygiene in cerebral palsy children in Sekolah Luar Biasa Bagian D Yayasan Pembinaan Anak Cacat, Sukajadi, Bandung is included in the bad criteria.

\section{REFERENCES}

1. Sinar Grafika. UUD 1945 Hasil Amandemen dan Proses Amandemen UUD 1945 secara Lengkap. $6^{\text {th }}$ Ed. Jakarta: Sinar Grafika. 2009. 58-59 pp.

2. Fokus Media. Undang-Undang Sisdiknas Sistem Pendidikan Nasional. Bandung. Fokus Media. 2009.

3. Harijanto S. Mencari Keberadaan Anak Cacat untuk Menfasilitasi Pendidikannya. Mendikdasmen. Tabloid Spirit, Dit. PSLB. 2008. 1 pp.

4. Direktorat Pendidikan Luar Biasa. Sekolah Luar Biasa di Indonesia. 9 9th Ed. Jakarta. 2006.

5. Saharso D. Cerebral Palsy Diagnosis dan Tatalaksana. Bagian Ke-4. Surabaya. Kapita Ilmu Kesehatan Anak. 2006. 1-18 pp.

6. Finn SB. Clinical Pedodontics. $4^{\text {th }}$ Ed. USA: WB. Saunders Company. 2003. p. 576-578.

7. Rosenbaum P. The Definition and Classification of Cerebral Palsy : Are We Any Further Ahead in 2006. Developmental Medicine \& Child Neurology. 2006;49(8):1-44

8. Mangunatmaja I. Kenali Cerebral Palsy (CP) Sejak Dini. Mutiara Bunda. Majalah Kesehatan Keluarga-Dokter Kita. 2008. 1-3 pp.

9. Kouch G, Poulsen S. Pediatric Dentistry - a Clinical Approach. Copenhagen: Munksgaard. 2001. 453-454 pp.

10. Wyne AH. Oral Health Knowledge in Patient of Saudi Cerebral Palsy Children. Neurosciences. 2007;12(4):306-11.

11. Stanford TW. Cerebral Palsy in Dentistry. A Brief Review from Assistant Proffesor. Deparment of Perio. Anne Stanford. 2000. 1 pp.

12. National Institute of Dental and Craniofacial Research. Practical Oral Care for People with Cerebral Palsy. Grampian. NIH. 2004. 1-4 pp.

13. Irmaleny. Prevalensi Karies dan Keadaan Kebersihan Mulut Anak-anak Penderita Cerebral Palsy di Sekolah Luar Biasa Bagian D Bandung. 
FKG Unpad. Skripsi. 1989. 41-48 pp.

14. Putri MH, Herijulianti E, Nurjannah N. IlmuPencegahan Penyakit Jaringan Keras dan Jaringan Pendukung Gigi. Jakarta: Buku Kedokteran EGC. 2012

15. Mc Donald RE, Avery DR. Dentistry for The Child and Adolescent. $7^{\text {th }}$ Ed. St. Louis: C.V. Mosby Company. 2000. 247-261 pp.

16. Michael GN, Henry HT, Fermin AC. Clinical Periodontology. $9^{\text {th }}$ Ed. Philadelphia WB: Saun- ders. 2002. 96-105, 182-188 pp.

17. Fedi PF, et al. Silabus Periodonti. $4^{\text {th }}$ Ed. Jakarta: EGC. 2000. 13-37, 73-75 pp.

18. Notoatmodjo S. Pendidikan dan Perilaku Kesehatan. Jakarta: PT. Rineka Cipta. 2003. 12-30 pp.

19. Paradipto. Penanganan Kesehatan Gigi dan Mulut pada Anak yang Menderita Cacat Mental. Denpasar. 2009. 